\title{
Life cycle of Scapholeberis armata freyi Dumont \& Pensaert, 1983 (Cladocera, Daphnidae)
}

\author{
Maria Carolina de Almeida Castilho ${ }^{1,2}$, Célio Wisniewski ${ }^{1}$ \& Maria José dos Santos-Wisniewski ${ }^{1}$ \\ ${ }^{1}$ Universidade Federal de Alfenas - UNIFAL-MG, Rua Gabriel Monteiro da Silva, 714, \\ CEP 37130-000, Alfenas, MG, Brasil \\ ${ }^{2}$ Corresponding author: Maria Carolina de Almeida Castilho, e-mail: mariacarolcastilho@hotmail.com
}

CASTILHO, M.C.A., WISNIEWSKI, C. \& SANTOS-WISNIEWSKI, M.J. Life cycle of Scapholeberis armata freyi Dumont \& Pensaert, 1983 (Cladocera, Daphnidae). Biota Neotrop. 12(4): http://www.biotaneotropica. org.br/v12n4/en/abstract?article+bn01112042012

\begin{abstract}
Knowledge of the life cycle of zooplankton species can provide information for a better understanding of the role of each species in the community and basic data for secondary production investigations. In this study, some life-cycle traits were measured for Scapholeberis armata freyi Dumont \& Pensaert, 1983 (Cladocera, Daphnidae), maintained under controlled conditions in laboratory cultures. Experiments were carried out in incubators at a temperature of $23.0^{\circ} \mathrm{C}$, photoperiod of 12 hours light/dark, and food supply (algal suspension of the chlorophycean Pseudokirchneriela subcapitata at $10^{5}$ cells. $\mathrm{mL}^{-1}$ and mixed suspension of yeast, and fish ration added per organism, at equal proportions) that were kept constant. Observations were made once or twice a day to record individual growth, age and size of primipara, as well as fecundity and longevity. S. armata freyi achieved a maximum size of $827 \mu \mathrm{m}$, while the primiparous instar measured $542 \mu \mathrm{m}$ on average, at an age of 5.86 days. The mean fecundity was 8 eggs.female ${ }^{-1}$ and the mean of total number of eggs produced by a female was 47.58. Embryonic development time was 1.9 days and the maximum longevity found was 31 days. In this study, the life cycle parameters of S. armata freyi presented are close to those found in other species of Daphnidae, under the same culture conditions of temperature and photoperiod. However, the longevity was greater than other species that received algae as food only. The quality and quantity of food are factors that control secondary production in aquatic ecosystems and an increase of food availability increases longevity and egg production. Thus the greater longevity and egg production observed for $S$. armata freyi can influence its secondary production.
\end{abstract}

Keywords: Anomopoda, zooplankton, longevity, fecundity, growth.

CASTILHO, M.C.A., WISNIEWSKI, C. \& SANTOS-WISNIEWSKI, M.J. Ciclo de vida de Scapholeberis armata freyi Dumont \& Pensaert, 1983 (Cladocera, Daphnidae). Biota Neotrop. 12(4): http://www.biotaneotropica. org.br/v12n4/pt/abstract?article+bn01112042012

Resumo: O conhecimento de parâmetros do ciclo de vida de organismos zooplanctônicos fornece importantes dados para o cálculo da produção secundária da espécie, além de informações sobre sua biologia. Este estudo visou obter informações sobre o ciclo de vida de Scapholeberis armata freyi Dumont \& Pensaert, 1983 (Cladocera, Daphnidae), cultivada em laboratório. Os experimentos foram mantidos em incubadora com temperatura de $23,0^{\circ} \mathrm{C}$, fotoperíodo de 12 horas luz/12 horas escuro e alimentação (suspensão da alga clorofícea Pseudokirchneriela subcapitata na concentração de $10^{5}$ cels. $\mathrm{mL}^{-1}$ e uma suspensão mista de fermento e ração de peixes em igual proporção) constantes. As observações foram feitas uma ou duas vezes ao dia para o acompanhamento do crescimento do corpo, idade, comprimento da primipara, fecundidade e longevidade. A primipara da espécie ocorreu com 5,86 dias e comprimento médio de $542 \mu \mathrm{m}$. A média do comprimento máximo foi $827 \mu \mathrm{m}$. A fecundidade média de $S$. armata freyi foi de 8 ovos fêmea ${ }^{-1}$.ninhada ${ }^{-1}$ e o número total de ovos produzidos por fêmea durante todo o ciclo de vida foi, em média, 47,58 ovos. O tempo de desenvolvimento embrionário foi de 1,9 dias e a longevidade máxima foi de 31 dias. Os parâmetros do ciclo de vida de $S$. armata freyi obtidos neste estudo são próximos aos encontrados para outras espécies da família Daphnidae cultivadas nas mesmas condições de temperatura e fotoperíodo. No entanto, a longevidade foi maior do que a observada para espécies que receberam apenas alga como alimento. A qualidade e quantidade de alimento são fatores que controlam a produção secundária em ecossistemas aquáticos e um incremento na alimentação aumenta a longevidade, desenvolvimento e produção de ovos. Conclui-se que a maior longevidade e produção de ovos observada para S. armata freyi pode influenciar a produção secundária desta espécie.

Palavras-chave: Anomopoda, zooplâncton, longevidade, fecundidade, crescimento. 


\section{Introduction}

Knowledge of the life cycle of zooplankton species can provide information for a better understanding of the role of each species in the community, basic data for secondary production investigations and information on its biology (Santos-Wisniewski et al. 2006).

Environmental factors can influence the growth, reproduction and survival of zooplankton. Among these factors, the quality of food and temperature are the most important. The development time is temperature dependent, while fecundity is related to food availability (Bottrell et al. 1976). Growth and reproduction are species characteristics influenced by environmental conditions, and the parameters of the species' life cycle are used indirectly to know its biology and distribution in specific environments, in addition to observations from the field (Güntzel et al. 2003).

Cladocerans reproduce asexually by parthenogenesis, a process in which unfertilized eggs give rise to amictic females. In unfavorable conditions such as overcrowding, low temperatures and food scarcity, males are produced (Rocha \& Güntzel 2000). Because Cladocera reach maturity quickly, the growth of their population and egg production is increased (Melão1999).

Cladocera is typically a freshwater group found in lentic water bodies worldwide. The species found in Brazil are distributed in seven families, and Daphnidae is numerically abundant. Thus, many studies have been done on taxonomy, abundance, morphology, distribution of Daphnidae and some aspects of their biology and ecology (Matsumura-Tundisi 1984, Rocha \& Matsumura-Tundisi 1990, Fryer 1991, Fonseca \& Rocha 2004, Rietzler et al. 2008).

Scapholeberis armata freyi belongs to the family Daphnidae and subfamily Scapholeberinae (Dumont \& Pensaert 1983). The species Scapholeberis armata has limited distribution in the United States and Canada; however, the subspecies $S$. armata freyi was found in Paraguay, Mexico (Ciros-Perez \& Elias-Gutierrez 1996) and Brazil (Elmoor-Loureiro 2000). Representatives of family Daphnidae usually occur in the limnetic zone of aquatic environments; however, S. armata is found in the littoral zone, where they live linked to water surface tension (Rocha \& Güntzel 2000).

Studies on the life cycle carried out in Brazil aimed to produce large quantities of these animals for fish food (Sipaúba-Tavares 1988, Sipaúba-Tavares \& Rocha 1994) and a few aimed at studying secondary production (Rocha \& Matsumura-Tundisi 1984, 1990, Hardy \& Duncan 1994, Melão 1997).

In this work data was obtained on the life cycle of the S. armata freyi, which may contribute to further studies of secondary production for Brazilian freshwater ecosystems and other countries, where this species or similar species occur. The body dimension, growth, embryonic development time and fecundity obtained from life cycle studies are used in the secondary production calculations.

\section{Materials and Methods}

The organisms for starting cultures were collected inside macrophyte stands in the littoral zone of a pond of the Heliodora district $\left(22^{\circ} 29^{\prime} 12^{\prime \prime} \mathrm{S}\right.$ and $\left.45^{\circ} 36^{\prime} 68^{\prime \prime} \mathrm{W}\right)$ in the southern region of Minas Gerais State, Brazil, by vertical and horizontal hauls using a zooplankton net of $68 \mu \mathrm{m}$ mesh size. In the laboratory, parthenogenetic females of $S$. armata freyi were isolated and placed in $2 \mathrm{~L}$ beakers containing reconstituted water. This culture media had $\mathrm{pH}$ 7.6, conductivity $140 \mu \mathrm{S} . \mathrm{cm}^{-1}$ and hardness $46 \mathrm{mg} \mathrm{CaCO} \mathrm{L}^{-1}$ in according to ABNT, (Associação... 2009). Experimental cultures were maintained in growing chambers at a constant temperature of $23.0 \pm 0.5{ }^{\circ} \mathrm{C}$ and 12 hours light.dark ${ }^{-1}$ photoperiod and fed on a suspension of the small chlorophycean Pseudokirchneriela subcapitata, cultured in Chu 12 medium and cropped in the exponential phase, at a concentration of $10^{5}$ cells. $\mathrm{mL}^{-1}$, and $0.02 \mathrm{~mL}$ of a mixed suspension of yeast and fish ration added per organism (Associação... 2009) at equal proportion.

Individuals were acclimated for about 10 generations (30 days). Ten females were isolated and maintained until the production of neonates. Thirty neonates less than 24 hours old were placed in polypropylene bottles of $50 \mathrm{~mL}$ and kept in a germination chamber with the temperature, light and feeding conditions as specified above. Culture media and food suspensions were completely renewed daily with a fresh suspension at the same temperature. Once or twice a day, the animals were observed under the stereomicroscope in order to determine the number of eggs produced per brood and the longevity. The growth of each individual was measured daily under an optical microscope, using a micrometric grid and a $40 \times$ magnification.

The cycle life parameters were obtained by nonlinear curve fitting using Chi-square minimization method using a Levenberg-Marquardt algorithm (Moré 1978) by Origin 8.0 software.

\section{Results}

The life parameters of $S$. armata freyi are presented in Table 1 . Neonates had a mean size of $281 \pm 21 \mu \mathrm{m}$, reaching maturity after $5.86 \pm 1.00$ days, with a mean size of $542 \pm 44 \mu \mathrm{m}$. Mean embryonic development time was $1.90 \pm 0.37$ days.

During its life cycle, $S$. armata freyi produced a mean of $7.00 \pm 1.80$ broods with a mean fecundity of $8 \pm 3$ eggs each. Egg production increased up to advanced-aged organisms as shown in Figure 1. The maximum and mean egg production in the whole life cycle was 98 and 65 eggs per female, respectively.

In the present study, three juvenile stages and 10 instars in the life cycle were recorded for $S$. armata freyi. The maximum longevity of $S$. armata freyi was 31 days and mean longevity was $23 \pm 4$ days. The mean maximum size was $827 \pm 51 \mu \mathrm{m}$. Mean individual growth curve of $S$. armata freyi is shown in Figure 2.

\section{Discussion}

The results for embryonic development duration (EDD), primiparous age (PA), fecundity $(\mathrm{F})$, longevity $(\mathrm{L})$ and temperature (T) of several Daphnidae are compared to other studies (Table 2).

The primiparous age of $S$. armata frey $i$ was close to those observed for Simocephalus serrulatus by Melão (1997). Thus, the maturity of $S$. armata freyi occurred later compared with Ceriodaphnia silvestrii (Fonseca \& Rocha 2004), Daphnia laevis and Daphnia ambigua

Table 1. Life cycle parameters of Scapholeberis armata freyi (Cladocera, Daphnidae) cultured at $23.0 \pm 0.5^{\circ} \mathrm{C}$ in a 12 hours light/dark photo period, fed on a mixed suspension of Pseudokirchneriela subcapitata (at $10^{5}$ cells. $\mathrm{mL}^{-1}$ ) and yeast, and fish ration added per organism, at equal proportions.

\begin{tabular}{lc}
\hline \multicolumn{1}{c}{ Life cycle parameters } & Values \\
\hline Adult mean size $(\mu \mathrm{m})$ & $827 \pm 21$ \\
Neonate mean size $(\mu \mathrm{m})$ & $281 \pm 21$ \\
Primipara mean size $(\mu \mathrm{m})$ & $542 \pm 44$ \\
Minimum size of primipara $(\mu \mathrm{m})$ & 400 \\
Number of instars between neonate and primipara & $3 \pm 0.6$ \\
Mean number of instars in the whole life cycle & $7 \pm 0.69$ \\
Mean number of eggs in the whole life cycle & $47.58 \pm 6.27$ \\
Mean fecundity (eggs/female/brood) & $8 \pm 3$ \\
Maximum longevity (days) & 31 \\
Mean longevity (days) & $23 \pm 4$ \\
Mean embryonic development times (days) & $1.9 \pm 0.37$ \\
Primipara mean age (days) & $5.86 \pm 1$ \\
\hline
\end{tabular}




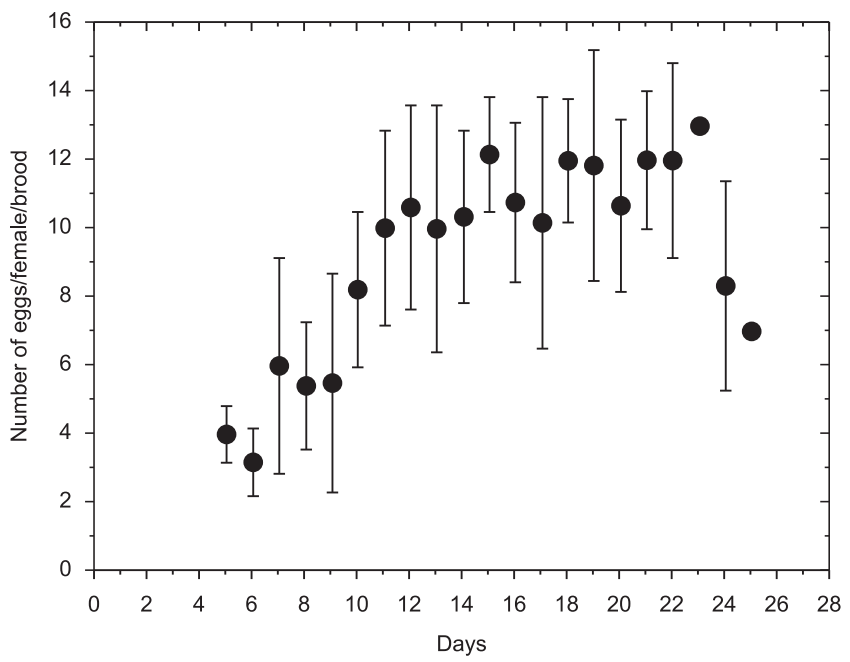

Figure 1. Mean fecundity (number of eggs.female ${ }^{-1} \cdot$ brood $^{-1}$ ) of Scapholeberis armata freyi (Cladocera, Daphnidae) cultured at $23.0^{\circ} \mathrm{C}$, in the 12 hours light/dark photo period, fed on a mixed suspension of Pseudokirchneriela subcapitata (at $10^{5}$ cells. $\mathrm{mL}^{-1}$ ) and yeast, and fish ration added per organism, at equal proportion.

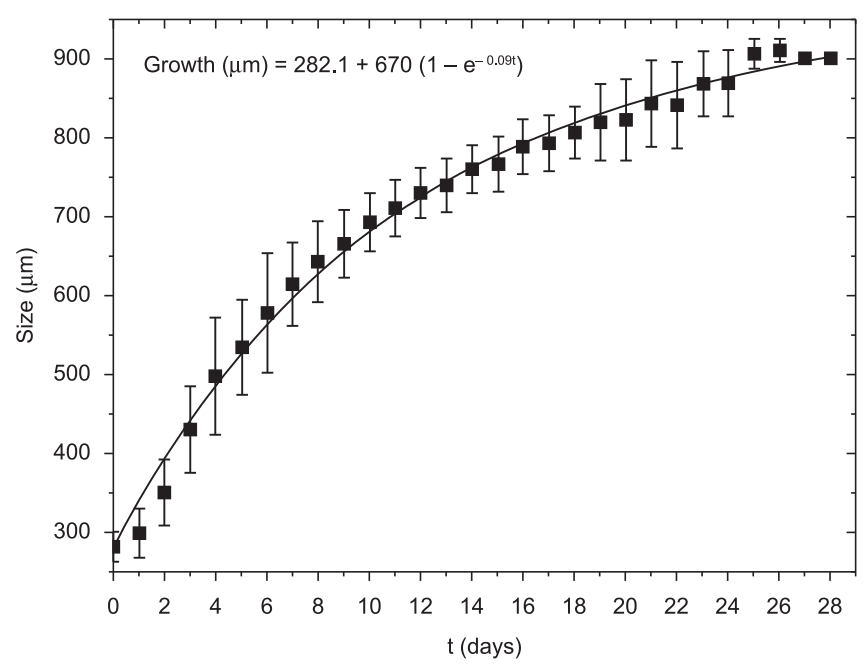

Figure 2. Mean individual growth curve of Scapholeberis armata freyi (Cladocera, Daphnidae) grown in the laboratory at $23.0{ }^{\circ} \mathrm{C}$, in the 12 hours light/12 hours dark photo period, fed on a mixed suspension of Pseudokirchneriela subcapitata (at $10^{5}$ cells. $\mathrm{mL}^{-1}$ ) and yeast, and fish ration added per organism, at equal proportion.

Table 2. Comparison of embryonic development duration (EDD), primiparous age (PA), fecundity (F), longevity (L) and temperature (T) from the present study and reported in the literature of several Daphnidae.

\begin{tabular}{lcccccl}
\hline \multicolumn{1}{c}{ Species } & DE (days) & PA (days) & F (days) & L (days) & T $\left({ }^{\circ} \mathbf{C}\right)$ & Author \\
\hline Scapholeberis armata freyi & 1,9 & 5,2 & 8 & 23 & 23 & Present study \\
Scapholeberis kingi & & & & 20 & 28 at 30 & Murugan \& Sivaramakrishnan (1976) \\
Ceriodaphnia sivestrii & & 3 at 4 & 9,46 & 29,8 & 25 & Fonseca \& Rocha (2004) \\
Ceriodaphnia cornuta & 3,24 & 4,76 & 2,2 & 9,8 & 20 & Melão (1997) \\
Simocephalus serrulatus & 2,58 & 5,18 & 22 & 13,4 & 20 & Melão (1997) \\
Daphnia laevis & 2 & 4,92 & 14,3 & & 25 & Rocha \& Matsumura-Tundisi (1990) \\
Daphnia gessneri & 2 & 7,38 & 9,07 & & 22 & Hardy \& Duncan (1994) \\
Daphnia ambigua & 2 & 4,25 & 7,12 & & 25 & Rocha \& Matsumura-Tundisi (1990) \\
\hline
\end{tabular}

(Rocha \& Matsumura-Tundisi 1990) at a temperature of $25 \pm 2{ }^{\circ} \mathrm{C}$. The primiparous age increased as a consequence of the lower experimental temperature in the current study, $23^{\circ} \mathrm{C}$, compared to the $25^{\circ} \mathrm{C}$ for the three species mentioned above. However, the age of the first reproduction for $S$. armata freyi was earlier than that observed for D. gessneri under the temperature of $22{ }^{\circ} \mathrm{C}$ (Hardy \& Duncan 1994). As the difference in temperature between the experiments is small, probably the species $C$. silvestrii, D. ambiguous and D. laevis reach maturity earlier than $S$. armata freyi because these species are typical of the limnetic region, where predation by planktivorous fish is higher, which accelerates the maturity of these organisms. This does not occur with $S$. armata freyi, typical of the littoral region. It can allocate more energy to body growth and, after this, invests in reproduction, since in the littoral region there is greater availability of food (Sarma et al. 2005).

The embryonic development duration of $S$. armata freyi was similar to that found for $S$. serrulatus at $25^{\circ} \mathrm{C}$ (Melão 1997). The same author obtained 2.58 days of embryonic development for $S$. serrulatus at $20^{\circ} \mathrm{C}$. Therefore, with an increase in water temperature, the duration of embryonic development decreases. Compared with species from other families of Cladocera, the time of embryonic development of $S$. armata freyi is close to 1.96 days, as recorded for Chydorus pubescens (Santos-Wisniewski et al 2006), and greater than 1 day observed for Moina minuta (Murugan 1975).
Mean fecundity in some species of this family was higher than that recorded for S. armata freyi, such as S. serrulatus (Melão 1997). D. laevis also showed high fecundity (Rocha \& Matsumura-Tundisi 1990). Normally, larger species have a greater number of eggs compared to the smaller species (Melão 1997), such as S. serrulatus (22 eggs.female frood $^{-1}$ ) and D. laevis (14.3 eggs.female . $^{-1}$ brood $^{-1}$ ) which are larger than $S$. armata freyi.

During its life cycle, $S$. armata freyi produced a mean of $7.0 \pm 1.8$ broods with a mean fecundity of $8 \pm 3$ eggs.female ${ }^{-1}$. brood $^{-1}$. The mean fecundity increased as the individual became older, so for the first brood it is, on average, 3 to 4 eggs, while in the third brood, this number increased to 8 eggs, and in the sixth brood it increases to 12 eggs; however, it falls to 9 eggs in the last brood. A similar pattern was observed for Macrothrix flabelligera, where the production increased from 5 to 18.5 eggs, starting with the fifth brood (Güntzel et al. 2003). Probably, in the first litters, S. armata freyi invests more energy in body growth and produces few eggs. Around the $14^{\text {th }}$ day of life, the rate of body growth decreases and more energy is allocated to reproduction. Near the end of the life cycle, egg production also decreases due to the aging.

The total egg production in the whole life cycle of $S$. armata freyi (98 eggs.female ${ }^{-1}$ ) is low compared to that observed for Scapholeberis kingi (239 eggs.female ${ }^{-1}$ ) with temperatures around 28 to $30{ }^{\circ} \mathrm{C}$ (Murugan \& Sivaramakrishnan 1976). The S. kingi female size 
ranges from $400 \mu \mathrm{m}$ to $1000 \mu \mathrm{m}$, therefore, the size is larger than $S$. armata freyi $(281 \mu \mathrm{m}$ to $827 \mu \mathrm{m})$. The highest temperature of the study was responsible for the high fecundity of $S$. Kingi, because the increase of temperature accelerates the metabolic processes and affects reproduction (Sarma et al. 2005).

During the study, three juvenile instars and seven adult instars were recorded for $S$. armata freyi. The number of juvenile instars is close to that of the $S$. kingi, which showed two juvenile instars and seventeen adult instars (Murugan \& Sivaramakrishnan 1976). According to Bottrell (1975) the number of juvenile instars in Cladocera is between three and eight, and is generally constant for each species. For Melão (1999), the number of juvenile instars is between two and four, not exceeding six. However, the number of instars could be higher than recorded, because the animal suffers some seedlings before the first neonate measure (Kotov 1997).

According to Dumont (1987), some species invest energy in a long lifetime and low reproduction, while others invest in reproduction yet their lifetime is lower. In this study, it was observed that body growth is rapid until the sixth day of life, when primiparous occurs. Although they continue to grow after primiparous, the organisms invest more energy in reproduction, and the growth rate is slower.

Compared with other species of Cladocera, the longevity of $S$. armata freyi is similar to that recorded for Euryalona orientalis (23.8 days) (Venkataraman 1990) and Leydigia acanthocercoides, with a mean longevity of 23.2 days (Murugan \& Job 1982). However, the latter two studies were conducted at high temperatures, 28 and $30{ }^{\circ} \mathrm{C}$, respectively.

The parameters of $S$. armata freyi are similar to those found in other species of Daphnidae cultivated under the same conditions (temperature and photoperiod). Primiparous and embryonic development time for $S$. armata freyi were close to those observed for $S$. serrulatus. Although, the longevity of $S$. armata freyi was higher than for S. serrulatus and Ceriodaphnia cornuta longevity (Melão 1997), because in these experiments the food source was algae, while in the present study, it was algae and a mixed suspension of yeast and fish ration. The quality and quantity of food are factors that control secondary production in aquatic ecosystems (Santos et al. 2010) and an increase of food availability increases longevity and egg production (Santos et al. 2006), thus the greater longevity and egg production observed for $S$. armata freyi can influence its secondary production.

According to Sarma et al. (2005), in tropical regions food availability and water temperature is higher than in temperate regions. Therefore, by offering more food (or richer food) during the experiment and increasing water temperature, the conditions approach those found in the tropics. Thus, under natural conditions, the variation in the water temperature, photoperiod and food availability are responsible for variations in the longevity, duration of the embryonic development and primiparous age.

\section{Acknowledgements}

The authors thank FAPEMIG (Projeto Biota Minas APQ03549-09 and Universal APQ 01518-09) and Furnas Centrais Elétricas S.A. (Programa de P\&D Aneel) for their financial support.

\section{References}

ASSOCIAÇÃO BRASILEIRA DE NORMAS TÉCNICAS - ABNT. 2009. NBR 12713: Ecotoxicologia aquática - toxicidade aguda- método de ensaio com Daphnia spp. (Cladocera, Crustacea). ABNT, Rio de Janeiro, 23p.
BOTTRELL, H.H. 1975. Generation time, lenght of life, instar duration and frequency of moulting, and their relationship to temperature in eight species of Cladocera from the River Thames, Reading. Oecologia 19:129-140. http://dx.doi.org/10.1007/BF00369097

BOTTRELL, H.H., DUNCAN, A., GLIWICZ, Z.M., HERZIG, A., HILLBRICHT-ILKOWSKA, A., KURASAWA, H., LARSSON, P. \& WEGLENSKA, T. 1976. A review of some problems in zooplankton production studies. Brow. J. Zool. 24:419-456.

CIROS-PEREZ, J. \& ELIAS-GUTIERREZ, M. 1996. Nuevos registros de cladóceros (Crustacea:Anomopoda) en México. Rev. Biol. Trop. 44(1):297-304

DUMONT, H.L. 1987. A population study of Scapholeberis rammneri Dumont and Pensaert (Cladocera:Daphniidae). Hydrobiologia 145:275-284. http:// dx.doi.org/10.1007/BF02530288

DUMONT, H.J. \& PENSAERT, J. 1983. A revision of the Scapholeberinae (Crustacea: Cladocera) Hydrobiologia 100:3-45. http://dx.doi. org/10.1007/BF00027420

ELMOOR-LOUREIRO, L.M.A. 2000. Ocorrência de Scapholeberis armata freyi Dumont \& Pensaert (Crustacea: Anomopoda, Daphniidae) no estado de São Paulo, Brasil. Rev. Bras. Zool. 17(1):301-302. http://dx.doi org/10.1590/S0101-81752000000100026

FONSECA, A. L. \& ROCHA, O. 2004. The life-cycle of Ceriodaphnia silvestrii Daday, 1902 a Neotropical endemic species (Crustacea, Cladocera, Daphnidae). Acta Limnol. Bras. 16(4):318-329.

FRYER, G. 1991. Functional Morphology and the Adaptive Radiation of the Daphniidae (Branchiopoda: Anomopoda) Phil. Trans. R. Soc. London B 331:1-99. http://dx.doi.org/10.1098/rstb.1991.0001

GÜNTZEL, A. M., ROCHA, O. \& MATSUMURA-TUNDISI, T. 2003. Life cycle of Macrothrix flabelligera Smirnov, 1992 (Cladocera, Macrothricidae) recently reported for the Neotropical region. Hydrobiologia 490(1-3):87-92. http://dx.doi.org/10.1023/A:1023414612650

HARDY, E. \& DUNCAN, A. 1994. Food concentration and temperature effects on life cycle characteristics of tropical Cladocera (Daphnia gessneri Herbst, Diaphanosoma sarsi Richard, Moina reticulada (Daday): I. Development time. Acta Amazonica 24:119-134.

KOTOV, A.A. 1997. A special moult after the release of the embryo from the brood pouch of Anomopoda (Branchiopoda, Crustacea) a return to an old question. Hydrobiologia 354:83-87. http://dx.doi. org/10.1023/A:1003063407127

MATSUMURA-TUNDISI, T. 1984. Occurrence of species of the genus Daphnia in Brazil. Hydrobiologia 112:161-165. http://dx.doi.org/10.1007/ BF00008082

MELÃO, M.G.G. 1997. A comunidade planctônica (fitoplâncton e zooplâncton) e produtividade secundária do zooplâncton de um reservatório oligotrófico. Tese de doutorado, Universidade Federal de São Carlos, São Carlos.

MELÃO, M.G.G. 1999. Desenvolvimento e Aspectos Reprodutivos de Cladóceros e Copépodos de Águas Continentais Brasileiras. In Perspectivas da Limnologia no Brasil (M.L.M. Pompêo, org.). Gráfica e Editora União, São Luís, p.45-57.

MORÉ, J.J. 1978. The Levenberg- Marquardt algorithm: Implementation and theory. Lect. Notes Math. 630:105-116. http://dx.doi.org/10.1007/ BFb0067700

MURUGAN, N. 1975. Egg production, development and growth in Moina micrura Kurz (1874) (Cladocera: Moinidae). Freshw. Biol. 5:245-250. http://dx.doi.org/10.1111/j.1365-2427.1975.tb00137.x

MURUGAN, N. \& SIVARAMAKRISHNAN, K.G. 1976. Laboratory studies on the longevity, instar duration, growth, reproduction and embryonic development in Scapholeberis kingi Sars (1903) (Cladocera: Daphnidae). Hydrobiologia 50:75-80. http://dx.doi.org/10.1007/BF00016844

MURUGAN, N. \& JOB, S.V. 1982. Laboratory studies on the life cycle Leydigia acanthocercoides Fisher (1854) (Cladocera: Chydoridae). Hydrobiologia 89:9-16. http://dx.doi.org/10.1007/BF00017533 
Castilho, M.C.A. et al.

RIETZLER, A.C., ROCHA, O., ROCHE, K.F. \& RIBEIRO, M.M. 2008. Laboratory demonstration of morphological alterations in Ceriodaphnia cornuta Sars (1885) fa rigaudi induced by Chaoborus brasiliensis Theobald (1901). Braz. J. Biol. 68(2):453-454. PMid:18660979. http://dx.doi.org/10.1590/S1519-69842008000200032

ROCHA, O. \& MATSUMURA-TUNDISI, T. 1984. Biomass and production of Argyrodiaptomus furcatus, a tropical calanoid copepod in Broa Reservoir, southern Brazil. Hydrobiologia 113:307-311. http://dx.doi. org/10.1007/BF00026617

ROCHA, O. \& MATSUMURA-TUNDISI, T. 1990. Growth rate, longevity and reproductive performance of Daphnia laevis Berge, D. gessneri Herbst and D. ambigua Scounfield in laboratory cultures. Rev. Bras. Biol. 50(4):915-921.

ROCHA, O. \& GUNTZEL, A.M., 2000. Crustacea Branchiopoda. In Invertebrados de água doce (D. Ismael, W.C. Valente, T. MatsumuraTundisi \& O. Rocha, eds.). BIOTA/FAPESP, São Paulo, v.4, p.109-120.

SARMA, S.S.S., NANDINI, S. \& GULATI, R.D. 2005. Life history strategies of cladocerans: comparisons of tropical and temperate taxa. Hydrobiologia 542:315-333. http://dx.doi.org/10.1007/s10750-004$3247-2$
SANTOS, M.A.P.F., MELÃO, M.G.G. \& LOMBARDI, A.T. 2006. Life history characteristics and production of Ceriodaphnia silvestrii Daday (Crustacea, Cladocera) under different experimental conditions. Acta Limnol. Bras. 18(2):199-212.

SANTOS, R.M., NEGREIROS, N.F., SILVA, L.C., ROCHA, O. \& SANTOS-WISNIEWSKI, M.J. 2010. Biomass and production of Cladocera in Furnas Reservoir, Minas Gerais, Brazil. Braz. J. Biol. 70(3 suppl.):879-887. PMid:21085793. http://dx.doi.org/10.1590/S151969842010000400019

SANTOS-WISNIEWSKI, M.J., ROCHA, O. \& MATSUMURA-TUNDISI, T. 2006. Aspects of the Life Cycle of Chydorus pubescens Sars, 1901 (Cladocera, Chydoridae). Acta Limnol. Bras. 18(3):305-310.

SIPAÚBA-TAVARES, L.H., 1988. Utilização do plâncton na alimentação de larvas e alevinos de peixes. Tese de doutorado, Universidade Federal de São Carlos, São Carlos.

SIPAÚBA-TAVARES, L.H. \& ROCHA, O., 1994. Cultivo em larga escala de organismos planctônicos para a alimentação de larvas e alevinos de peixes: I-algas clorofíceas. Biotemas 6(11):93-106.

VENKATARAMAN, K. 1990. Life-history studies on some cladoceran under laboratory conditions. J. And. Sci. Assoc. 6:127-132. 